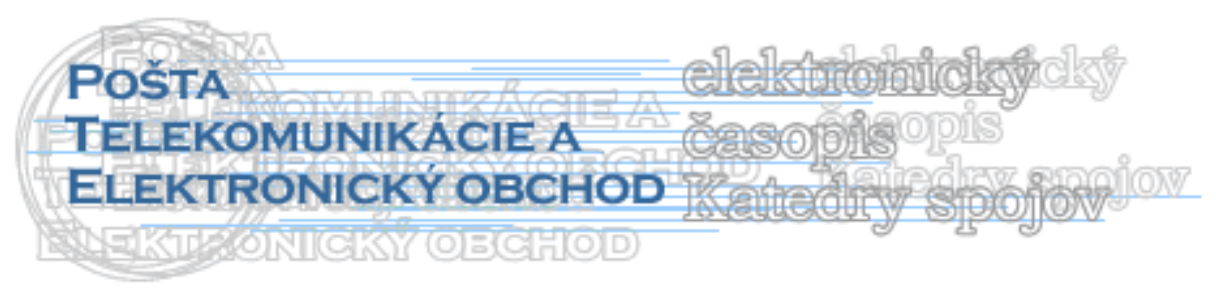

\title{
EKONOMIKA RFID
}

\author{
Martin Vaško, Juraj Vaculík*
}

\section{Úvod}

V súčasnosti dochádza $\mathrm{k}$ mohutnému rozmachu rôznych nových technológií, ktoré majú podnikom $\mathrm{v}$ jednotlivých odvetviach a sektoroch národných hospodárstiev pomôct' zvyšovat' svoju efektivitu, výkonnost' a tým aj ich konkurencieschopnost'.

Jednou z týchto technológií je aj rádio-frekvenčná identifikácia (RFID), o ktorej môžeme povedat', že spadá do oblasti informačných technológií a teda sa s ňou spája aj vel'ké množstvo problémov, ktoré sú príznačné pre celú túto skupinu. Ak opomenieme najčastejšie problémy, ktoré sú technického rázu, vystúpi do popredia hlavne problém vyjadrenia ekonomickej efektívnosti ich implementácie do zabehnutých podnikových procesov. Jeho podstatou je hlavne ich zložitost' a fakt, že zasahujú do vel'kého množstva aktivít v podniku.

$\mathrm{V}$ d'alšom texte sa pokúsime o bližšie analyzovanie tohto problému a následné odpovedanie na otázku: „Čo všetko treba zohl'adnit', pri nasadzovaní RFID technológie, resp. ako kvantifikovat' náklady a prínosy súvisiace $\mathrm{s}$ implementáciou týchto systémov do podnikových procesov?“.

\section{Rádio-frekvenčná identifikácia}

Princíp fungovania a základné vlastnosti RFID technológie boli podrobne popísané v dvoch predchádzajúcich číslach tohto časopisu v článkoch „Možnosti identifikácie pomocou RFID technológie“, „RFID middleware v poštových službách“ a v „Implementácia RFID v prostredí SCM“. Ako si čitatel' mohol všimnút' v poslednej menovanej práci, medzi odporúčanými krokmi pre proaktívnu implementáciu RFID systémov je hned' na prvom mieste uvedená tvorba štúdie ROI (Return on Investment: návratnost' investícií) pre RFID.

Z uvedených prác o rádio-frekvenčnej identifikácii je zrejmé, že táto technológia môže byt' využitá $\mathrm{v}$ širokom spektre podnikových aktivít a procesov. V súčasnosti sa RFID systémy využívajú hlavne vo výrobe, dodávatel'ských ret'azcoch, doprave, skladovaní, ale začínajú sa v stále väčšej miere presadzovat' aj v maloobchode, zdravotníctve a evidencii majetku. Implementácie môžeme samozrejme nájst' aj v rôznych dochádzkových systémoch a iných oblastiach využitia.

Ak vezmeme do úvahy popísanú rôznorodost' možných využití, odlišností jednotlivých RFID sytémov, rôzne prístupy ich výrobcov a dodávatel'ov a v neposlednom

\footnotetext{
*Ing. Martin Vaško, Žilinská univerzita v Žiline, Fakulta Prevádzky a ekonomiky dopravy a spojov, Katedra spojov, Univerzitná 1, 01026 Žilina, tel.: +420 4151331 45, e-mail: martin.vasko@fpedas.uniza.sk 
rade aj špecifické požiadavky konečných uživatel'ov, uvedomíme si, že nájst' presnú metódu na peňažné posúdenie efektívnosti konkrétneho systému je vel'mi náročná úloha.

\section{Ekonomika RFID}

Z hl'adiska podniku, ktorého hlavným ciel’om je generovanie zisku, je pri posudzovaní investície do novej technológie dôležité najmä správne posúdenie prínosov a rizík, ktoré súvisia $\mathrm{s}$ jej zavedením. Môžeme povedat', že dôraz sa kladie hlavne na ekonomickú návratnost' a peňažný prínos vloženej investície.

$\mathrm{Na}$ to, aby sme boli schopný peňažne vyjadrit' návratnost' konkrétnej investície (ROI, Return On Investments), potrebujeme poznat' zisk a všetky úspory, ktoré s ňou súvisia na jednej strane a náklady na jej realizáciu na strane druhej. Ako už bolo spomenuté, problémom pri informačných technológiách je fakt, že ich prínos sa prejavuje $\mathrm{v}$ mnohých častiach podniku a vôbec nie je jednoduché ich všetky identifikovat' a dostatočne popísat'. Z tohto dôvodu je použitie nasledujúcej metódy, ktorá sa bežne používa, vel'mi zložité.

$$
\text { ROI RFID }=\frac{\text { Zisk zinvestície }- \text { Náklady investície }}{\text { Náklady investície }}
$$

Pozrime sa teda, čo všetko si treba všímat' a brat' do úvahy, aby sme mohli vyjadrit' návratnost' investície do rádio-frekvenčnej identifikácie.

\section{Prínosy}

Základným ciel’om pri implementácii RFID systému v podniku je efektívne získavanie informácií, ktoré svojou povahou umožnia zmeny $\mathrm{v}$ podnikových procesoch a teda povedú $\mathrm{k}$ zvýšeniu výkonnosti a zníženiu nákladov. Práve zlepšovanie jednotlivých procesov a znižovanie nákladov má viest' $\mathrm{k}$ tomu, aby sa podniku vrátili zavádzacie náklady a výdavky súvisiace s prevádzkou daného RFID systému.

Pritom už nezáleží na tom, či sa v konečnom dôsledku jedná o efektívnejšie sledovanie a riadenie zásob, obmedzenie omylov pri dodávkach produktov, zvýšenie spokojnosti zákazníka, obmedzenie krádeží, alebo výkonnejší systém sledovania a riadenia výroby.

Ďalším prínosom, ktorý môže takýto systém podniku poskytovat' je zabezpečenie informácií získavaných $\mathrm{v}$ reálnom čase, ktoré môžu vylepšit' rozhodovacie procesy manažmentu, eliminovat' rôzne neefektívnosti, optimalizovat' využívanie podnikového vybavenia (zariadenia, automobily, iné drahé položky), alebo môžu pomôct' pri zabezpečovaní konzistentných služieb zákazníkom. Tieto informácie už majú charakter, ktorý môže prinášat' finančný prospech podniku aj z dlhodobého hl'adiska.

Možno konštatovat', že skutočná hodnota RFID systému spočíva $\mathrm{v}$ jeho schopnosti pomôct' podniku dosiahnut' takú úroveň (efektívnych) procesov, ktorá by bez rádiofrekvenčnej identifikácie vôbec nebola možná. Taktiež treba uviest', že tieto systémy nemusia byt' nevyhnutne nasadzované do podniku "globálne", ale že majú zmysel aj v prípade nasadenia na špecifické aktivity alebo procesy. V takýchto prípadoch sa ich pozitívny účinok môže objavit' v relatívne krátkom čase.

Z benefitov, ktoré sa dajú popísat' aj menej abstraktným spôsobom a ktoré možno relatívne l'ahko vyjadrit' peňažne, možno uviest' napríklad úsporu pracovnej sily, prípadne zníženie počtu defektov vo výrobe. Tie sú už svojou povahou l'ahšie popísatel'né, čo výrazne pomáha pri peňažnej kvantifikácii celkových prínosov.

Na tomto mieste je vhodné uviest', že jednou z metód, ktoré sú úspešne používané v praxi na posúdenie prospešnosti investície obsahujúcej väčšie množstvo efektov $\mathrm{s}$ 
nefinančnou a niekedy dokonca nehmotnou povahou, je CBA - Cost Benefit Analysis. CBA je metodický postup, ktorý svojím priebehom odpovedá na základnú otázku: "Čo komu realizácia investičného projektu prináša a čo komu berie?". Takto vymedzené dopady akcie sú následne agregované, prevedené na hotovostné toky a zahrnuté do výpočtov rozhodujúcich ukazovatel'ov, na základe ktorých sa rozhoduje, či daný projekt prijat', alebo nie.

\section{Náklady}

Pre finálne posúdenie návratnosti investícií do RFID systému potrebujeme poznat'aj opozitum prínosov - náklady. Stanovenie nákladov na zavedenie a prevádzkovanie RFID technológie je tak isto zložité, ako posudzovanie prínosov. Pridáva sa ešte aj fakt, že kým sa pri hodnotení prínosov pozeráme na RFID systém ako na celok, pri analyzovaní nákladov je výhodné dekomponovat' ho na jednotlivé prvky tak, ako boli popísané v článkoch, ktoré sú uvedené na začiatku - čítacie zariadenia, tagy a middleware. Treba taktiež zohl'adnit' všetko, čo sa inštalovanej RFID siete dotýka: personál, IT infraštruktúra, podnikové procesy a priestory, $\mathrm{v}$ ktorých budú jednotlivé rádio-frekvenčné zariadenia inštalované.

Najčastejšie sa pri posudzovaní finančnej náročnosti RFID implementácie pozerá iba na cenu čítacích zariadení a tagov, čo je vel'ká chyba. Náklady kompletného systému takejto auto-identifikácie okrem tagov a čítačiek zväčša zahŕňajú aj obslužný softvér, školenia zamestnancov, prípadné upgrady už zabehnutého informačného systému a jeho aplikácií a náklady na prepracovanie niektorých procesov, ktorých sa nový systém dotkne. Niektoré sa môžu dokonca úplne zrušit'.

RFID tagy zvyčajne tvoria iba 15 až 25 percent celkových nákladov na RF systém, aj ked' ide o opakujúcu sa nákladovú položku. Napriek tomu často na seba spolu s čítacími zariadeniami strhnú väčšinu pozornosti, čo vedie $\mathrm{k}$ prehliadnutiu celkového dopadu rádiofrekvenčného systému na podnikovú infraštruktúru a ostatné procesy. Následné "neočakávané" náklady sú jednou $\mathrm{z}$ najčastejších hrozieb, ktorá ohrozuje úspešné implementovanie týchto systémov do podnikovej praxe.

Cena tagov sa výrazne líši v závislosti od ich typu a množstva, ktoré podnik plánuje nakúpit' a používat'. Je prirodzené, že pasívne tagy sú lacnejšie ako výkonnejšie aktívne a cena na kus pre odberatel'a klesá s narastajúcim množstvom v objednávke. Ďalším dôležitým faktorom, ktorý ovplyvňuje ich cenu je možnost' recyklácie. Treba však dodat', že viacnásobné využívanie tagov nie je vhodné, prípadne možné vo všetkých prípadoch.

Ceny čítačiek sa taktiež líšia podl'a toho, aká je ich funkcionalita a vybavenost'. Niektoré RFID systémy síce využívajú vel'mi lacné tagy, ale na druhej strane ich obsluhujú drahé čítačky, čo môže byt' nevýhodné pri aplikáciách s potrebou vel'kého počtu čítacích zariadení. Tieto systémy sú vhodné tam, kde je potrebné vel'mi vel'ké množstvo tagov, ktoré sa zaznamenávajú iba na pár miestach. Opakom sú prípady, ked' podnik potrebuje sledovat' drahé zariadenia na rôznych miestach. Takáto situácia často vyžaduje použitie menšieho počtu drahých a odolných tagov a väčšieho množstva lacných, prenosných čítačiek.

Ako už bolo uvedené, inštalovaný systém rádio-frekvenčnej identifikácie má zväčša výrazné dopady na podnikové procesy. Niektoré môžu byt' úplne zrušené a pri iných je len zvýšená efektivita. $Z$ dlhodobého hl'adiska síce hovoríme o prínosoch a úsporách, treba si však uvedomit', že zavádzanie RFID vel'akrát pôsobí (hlavne v prvotných etapách) na tieto procesy rušivo. Nejaký čas trvá, kým sa inštalujú jednotlivé zariadenia, kým sa odladia chyby a samozrejme, kým sa prispôsobí samotný proces tak, aby bol s novou technológiou kompatibilný. Toto všetko môžeme z hl'adiska nákladov popísat' prácou l'udí, ktorých musí podnik najat', alebo alokovat' z iných pracovných pozícií.

Počas analýzy nákladov a výnosov by sa nemalo zabúdat' ani na náklady súvisiace so školeniami zodpovedných pracovníkov. V prípade, že sa podnik rozhodne využivat’ RFID 
systém, musí rátat' s tým, že bude potrebovat' pracovníkov zodpovedných za prevádzku, údržbu a školenia nových a stávajúcich pracovníkov tak, aby títo boli schopný daný systém obsluhovat' a využívat' $v$ plnej miere. Z hl'adiska dostatočnej odbornosti zodpovedných pracovníkov je vhodné, aby sa zúčastnili aj inštalácie a testovania nasadzovanej technológie. Len v takomto prípade budú naozaj zžitý s novým systémom a budú mu skutočne rozumiet', čo sa následne prejaví aj po finančnej stránke.

Drvivá väčšina podnikov po rozhodnutí zaobstarat' si technológiu umožňujúcu automatickú identifikáciu siahne po službách špecializovaných firiem, ktoré majú s jej nasadzovaním skúsenosti a majú k dispozícii odborný personál. Takéto využitie outsourcingu zabezpečí, že všetky časti systému budú nainštalované správne a výsledný celok bude pracovat' k úplnej spokojnosti užívatel'a. Treba mysliet' aj na to, že proces samotnej montáže môže vyžadovat' rôzne modifikácie podnikovej infraštruktúry, prípadne stavebné úpravy.

Potom, čo sú všetky komponenty na svojom mieste dochádza $\mathrm{k}$ záverečnému doladeniu a pristupuje sa $\mathrm{k}$ testovaniu, ktoré musí byt' úspešné, aby sa daný systém mohol spustit' do plnej prevádzky. Všetky tieto činnosti si samozrejme nechajú externý dodávatelia zaplatit', čo výrazným spôsobom navyšuje uvádzacie náklady investície.

Prevádzka a údržba taktiež vel'kou mierou prispievajú $\mathrm{k}$ celkovým nákladom súvisiacim s využívaním RFID technológie. Tieto dva pojmy zahŕňajú najmä opakujúcu sa potrebu tagov (aj v prípade ich recyklácie) a potrebu vol'ných čítačiek, antén a iných prvkov systému, ktoré musí mat' užívatel' k dispozícii pre prípad hardvérovej poruchy niektorého z nich. Ďalšie výdavky tvoria napríklad technická podpora od dodávatel'a, oprava chýb a porúch, optimalizácia informačnej infraštruktúry atd’.

\section{Zhodnotenie}

Ako môžeme vidiet', prínosy a náklady súvisiace s implementáciou rádio-frekvenčnej identifikácie do aktivít podniku majú často nefinančnú a nehmotnú povahu. Tento fakt výrazne komplikuje posudzovanie finančnej efektívnosti RFID, ale aj iných informačných technológií. $Z$ tohto dôvodu by mali podniky, ktoré uvažujú o zavedení niektorej z nich:

- určit', na čo (a či naozaj) potrebujú uvažovaný systém,

- čo najpresnejšie kvantifikovat' očakávané prínosy,

- čo najpresnejšie určit’ celkové náklady súvisiace s implementáciou,

- porovnat' vyčíslené náklady s očakávanými prínosmi, určit' dobu návratnosti, prípadne d'alšie ukazovatele,

- zvážit', či zistené predpoklady spĺñajú ich očakávania a

- nakoniec sa rozhodnút', či daný systém budú implementovat'.

Dodržanie tejto metodiky by malo v maximálnej miere znížit’ riziko investovania do nevhodnej, či finančne neefektívnej technológie.

\section{Literatúra}

[1] ANDRECHAK, WILSON, ZIMMARDI, RFID Item Level Management, Mullaney publishing group, 2007, ISBN: 978-0971209909

[2] GLOVER, B., BHATT, H. RFID Essentials, Sebastopol: O'Reilly Media, Inc., 2006, ISBN 0-596-00944-5

[3] RFID Applications: Determining the Total Cost of Ownership (TCO), dostupné z http://www.abrfid.com/rfid/articles/cost-of-ownership.aspx

[4] RFID Adoption Stalls: Executive Summary, dostupné z http://www.computereconomics.com/article.cfm?id=1203 
[5] RFID portal, Jaké jsou př́nosy a výhody RFID?, dostupné z http://www.rfidportal.sk/index.php?page=pouziti-prinosy_rfid

[6] http://www.investopedia.com/terms/r/returnoninvestment.asp

[7] MICHÁLEK, I., VACULÍK, J.: Implementácia RFID systémov v prostredí SCM; Pošta, Telekomunikácie a Elektronický obchod, Žilina, II/2009, ISSN 1336-8281

[8] PAĎOUROVÁ, A., MAJERČÁKOVÁ, M.: Možnosti identifikácie pomocou RFID technológie; Pošta, Telekomunikácie a Elektronický obchod, Žilina, I/2009, ISSN 1336-8281

[9] VAŠKO, M., VACULÍK, J.: RFID middleware v poštových službách; Pošta, Telekomunikácie a Elektronický obchod, Žilina, II/2009, ISSN 1336-8281

\section{Grantová podpora}

Projekt aplikačného výskumu - 4/2045/08 - Aplikácie technológie RFID pre vybrané poštové procesy na podmienky HSS. 